\title{
Non-financial Risk Disclosure: From Narratives to an Index based on Delphi Technique
}

\author{
ADIBAH JAMIL, MOHAMAT SABRI HASSAN, NORMAN MOHD SALLEH, RUBAYAH \\ YAAKOB
}

\begin{abstract}
The inconsistency in research findings on the level of non-financial risk disclosure might be due to the measurement applied in prior studies. Prior studies measured non-financial risk disclosure by using manual text analysis. The results only covered types of non-financial risk disclosures that are only being reported in the company's annual report, which is significant to the shareholders but not for the other stakeholders. However, stakeholders view is important as it will lead to long-term performance. Hence, the present research aims to identify non-financial risk information based on stakeholders' expert opinions captured through a Delphi technique and ultimately to develop a non-financial risk disclosure index (NFRDI) which will benefit all stakeholders. This index is imperative as it will lead to most significant non-financial risk as it is based on the needs of all stakeholders as compared to excessive information prepared by the researchers. This study uses a sample comprising 313 companies listed in Bursa Malaysia from 2016 to 2018 to investigate level of non-financial risk disclosure among non-financial companies. Following a content analysis, the companies' annual reports were examined using the NFRDI. Findings show that non-financial risk reporting in Malaysian public-listed companies is still inadequate. However, the disclosure of several non-financial risk items has increased from 2016 to 2018. These results reveal that listed companies need to improve their risk reporting for the benefit of the stakeholders. This study contributes to fill the gap by identifying the risk factors and types of non-financial risks that are relevant to the investors and other stakeholders from the perspectives of experts. The NFRDI crafted is expected to be useful to the regulators and listed companies to enhance a transparent nonfinancial risk disclosure.
\end{abstract}

Keywords: Content analysis; Delphi technique; Disclosure index; Non-financial risk; Stakeholders' opinion.

\section{INTRODUCTION}

The negative impact of the financial crisis particularly, in Asia around 1997 and 1998 was claimed to be associated with insufficient information on risk and uncertainties (Barth \& Landsman 2010). Consequently, companies increased their risk reporting or risk disclosure (Jorgensen \& Kirschenheiter, 2003) as a response to pressure from regulators (Leopizzi, Lazzi, Venturelli \& Principale 2019; Bravo 2017). Within the current environment, risk disclosure is important specifically when the risk level of investment is high (Abraham \& Cox 2007; Linsley \& Shrives 2006) and companies are in a pressure to attract the financial analysts (Sundgren, Maki \& Somoza-Lopez 2018; Lehavy, Li \& Merkley 2011), investors, and professional (Abraham \& Shrives, 2014). However, prior studies have found that risk reporting is still inadequate as the level of disclosure still low (Tirado-Beltrán, Cabedo, \& Muñoz-Ramírez 2020) specifically for non-financial risks (NFR) as the companies and regulators always pay attention to financial risk disclosure, which has been subject to various regulations such as Bursa Malaysia Listing Requirement and The Malaysian Financial Reporting Standards. This event might be contributed by the complexities of regulating risk reporting (Elshandidy, Neri, \& Guo 2018). Therefore, understanding the situation of the company's economic environment does not help the users of the annual reports (Abraham \&Shrives 2014). Inconsistent risk disclosure can affect the investment decision-making process and can bring the burden of losses to investors (Tan, Zeng \& Elshandidy 2017; Abdullah, Abdul Shukor, Mohamed, \& Ahmad 2015; Lajili \& Zeghal 2005). Stakeholders, particularly investors need useful risk information to guide them in understanding the risk profiles faced by the company (Miihkinen 2013). Lack of informed investors and access to inaccurate information (Balkiz 2003) may lead to wrong decision making. Many of risk disclosure studies have established that stakeholders are typically preferred companies that are being transparent in their reports. However, whether the company's reporting of NFR disclosure (NFRD) truly satisfies stakeholders' expectations to understand the company's situation and future performance is still unclear.

Specifically, in a voluntary setting, companies are urged to strengthen their risk reporting by describing the risk factors they are facing (Garefalakis, Sariannidis \& Lemonakis 2018). Despite the importance of risk disclosure to the stakeholders, the NFRD is mainly based on the management discretion (Cheung, Jiang \& Tan 2010) to meet the shareholders' interest. Thus, companies were observed to provide inadequate, imprecise, or even distorted information which eventually denies the other stakeholders' right to make correct decisions. With that regard, researchers have proposed 
recommendations on non-financial risk information (NFRI), which will be disclosed in the annual reports. However, the issue with studies on voluntary disclosure is that researchers tend to propose information which they believe significant for decision making, without a proper consultation with the relevant stakeholders to determine their expectations and needs from the organization (Frooman 1999). This will lead to excessive non-financial risk information as these studies tend to focus on quantity rather than quality (Shivaani, Jain \& Yadav 2019; Jia, Munro \& Buckby 2016) and relevant information. Engagement with stakeholders is consistent with the marketing approach to responsive management (MARM). MARM was developed in 1986 by Keith Murray and John Montanari, which is consistent with Freeman's (1984) stakeholders' approach (Jurgens, Berthon, Papania, \& Shabbir 2010). Jurgens et al. (2010) stated that based on Murray and Montanari's (1986) view, once the stakeholders' needs are met, the firm will develop a good reputation for other stakeholders, including employees and existing and new customers, and new investors. Therefore, failure to engage stakeholders may lead the researchers to suggest a bundle of risk information. This event might not be relevant for some stakeholders and considering the high cost of disclosure to the companies, the items to be disclosed should be revisited. Furthermore, prior studies highlighted divergent or conflicting findings, which according to Worrell, Di Gangi, and Bush (2012) would indicate a lack of broad consensus and support the need for expert judgment to forge a path forward.

Therefore, what exactly the stakeholders' desire in understanding the risk a company is facing is worth revealing so that only relevant NFRI will be published by the companies thereby reducing their cost of disclosure. Since the disclosure of NFRI in Malaysia is still on a voluntary basis, the manager has the right to reveal or not to reveal the details in the annual reports. Therefore, some risks information might be purposely hidden to protect the interest of manager or the company although such information is worth for stakeholders' decision making (Leopizzi, Lazzi, Venturelli \& Principale 2009; Abdullah et al. 2015; Abraham \& Shrives 2014). The disclosure index is one of the ways in which voluntary information was assessed in the annual report (Marston \& Shrives 1991), and has been applied in previous studies such as Inchausti (1997), Hassan, Mohd Saleh, Yatim, and Che Abdul Rahman (2012), and Madrigal, Guzmán, and Guzmán (2015). Hence, the present study seeks to develop an NFRD index (NFRDI) using the Delphi technique, involving a group of stakeholders who are risk management experts. The Delphi method is a systematic technique aimed at obtaining a panelist's independent judgment, opinion, and consensus on a particular issue. The method is useful in reducing ambiguity using expert panels and informing relevant and timely issues faced by organizations (Worrell, et al. 2012). In this study, the method will lead to consensus among the experts on the items to be disclosed, which will form the NFRDI. Thus, unlike previous risk disclosure research, the current study contributes to the literature by developing NFRDI based on consensus among selected stakeholders. The index is categories into six categories of NFRD which the panels consider to be relevant for the awareness of the stakeholders. The index provides a single summary indicator of non-financial risk information in the annual reports and will enable preparers to provide the best practice of the information that benefits all stakeholders owing to its relevance and importance (Coy \& Dixon 2004). In addition, this study examines the level of risk disclosure among Malaysian-listed companies and finally identifies any difference between the experts' expectations on the risk disclosure in annual reports and the actual practice of risk reporting among companies.

The paper is organized as follows. Section 2 reviews previous research on voluntary risk reporting. Section 3 provides a brief description of the development of the NFRDI. Section 4 presents a description of the data and empirical method. Section 5 presents and discusses the findings, and finally, Section 6 concludes the study.

\section{VOLUNTARY RISK DISCLOSURE}

Developed countries, such as Germany, Finland, and the United Kingdom, have specific guidelines for companies to report financial and non-financial risk information (Miihkinen 2013). For example, the German Accounting Standard and the Finnish Accounting Practice Board require companies in respected countries to disclose the types of risks the company is facing, the methods used to manage risks, and the types of risks expected to be faced (Miihkinen 2013). Such comprehensive disclosure of risk information is a sign of a reliable risk management practice to the stakeholders (Dominguez \& Gamez 2014). However, for companies in developing countries, such as Malaysia, NFRI is voluntary, either as the best practice under Paragraph 9.1 of Malaysian Code of Corporate Governance 2017 (Securities Commission of Malaysia 2017) or to be disclosed in the annual reports by the Bursa Malaysia Listing Requirement (Bursa Malaysia 2018). The Malaysian Financial Reporting Standards (MFRS) also has no specific disclosure guidelines for risk information except for financial risk which is subject to paragraphs 31 and 32 of MFRS 7 Financial Instrument: Disclosure (Malaysian Accounting Standards Board 2012). Unlike the disclosure of financial risk that has been regulated and often required to be disclosed by regulators, there are no specific guidelines for non-financial risk information available. As a result, managers have discretion to report or not report non-financial risk information. The absence of specific guidelines also leads to varying disclosure of NFRI, such as operational, strategic, integrity, and empowerment risks, among listed companies. Investors seek for useful and reliable risk information to ascertain all risks faced by companies in their decision making (Miihkinen 2013). Inconsistent risk information disclosure can affect the investment decision-making process and can bring the burden of losses to investors (Tan et al. 2017, Abdullah et al. 2015, Lajili \& Zeghal 2005). Nevertheless, investors need useful risk information to guide them in understanding the risk profiles faced by the company (Miihkinen 2013). By contrast, a low level of NFRD may 
broaden information asymmetry between the management and the shareholders (Semper \& Beltran 2014), which leads to an increase in the cost of capital.

Measuring of the breath of voluntary information, such as non-financial risk, is one of the major limitations acknowledged in prior studies (Cheung et al. 2010). Abdullah et al. (2015), Dominguez and Gamez (2014), Abraham and Cox (2007), and Linsley and Shrives (2006) examined risk reporting based on narrative content analysis of risk categories or checklist of risk items (Table 1 presents some of the checklist items). The checklist was adapted from either prior studies (e.g., Abdullah et al. 2015; Ntim, Lindop \& Thomas 2013; Linsley \& Shrives 2006) or extending prior studies (Miihkinen 2013; 2012). However, Khlifa and Hussainey (2016) and Drees and Heugens (2013) stated that the narrative content analysis might be vulnerable to biased representations of a body of literature and might lead to false inferences. Furthermore, the checklist does not consider the views or requirements of NFRI from most stakeholders and is solely focused on the information that has been reported in the annual reports (Cheung et al. 2010). Furthermore, past studies asserted that in analyzing risk information reporting, a researcher must pay attention to not only the amount of information disclosed but also the issues relating to "what information is disclosed" (Beretta \& Bozzolan 2004).

The above arguments are consistent with the stakeholder theory considering that different stakeholders, such as employees, auditors, investors, government agencies, and financial institutions, require different risks information for their specific decision making (Abraham \& Shrives 2014). After all the shareholders' value maximization is no longer the goal of the organizations in the 21st century, as companies should be serving all stakeholders by maximizing the multiple stakeholders' value (Denning 2019). Therefore, a new framework for NFRD which meets the stakeholders' expectation should be prompt to meet the new corporate purpose. In line with the stakeholders' theory's views that a corporation is obligated to the shareholders and other stakeholders, such as employees and communities (Jurgens et al. 2010), this study believes that all stakeholders' view has to be incorporated in the management strategic driver, such as the NFRD. Modifying the MARM approach, Jurgens et al. (2010) proposed four steps to incorporate the stakeholders' view in corporate strategic decision making. First, key stakeholders' needs that the companies should meet must be identified. Second, stakeholders' group expectations and needs, problems, and potential strategic threats to the company should be determined. Third, policies and behaviors required to meet stakeholders' expectations through dialogue with the key stakeholders must be developed. Fourth, stakeholders' satisfaction with the new policies based on comments in the public media which might affect the company's public reputation should be monitored.

Based on the new development in the business environment, this study believes that the checklist of risk items has to be endorsed as relevant for the key stakeholders' decision making in form of corporatism, that is, single decision making (Jurgens et al. 2010). The corporations in Malaysia mostly focus on maximizing shareholder value. However, in some organizations, such as government-linked companies (GLC), other stakeholders' (e.g., government, people, and special interest groups) objective also needs to bet met. Therefore, the view of all relevant stakeholders based on a view of a coalition of various participants on the importance of NFRD is timely. This notion is consistent with findings from corporate voluntary reporting studies like Shivaani, Jain and Yadav (2020), Sahari (2017), Abdullah et al. (2015), and Coy and Dixon (2004). These studies indicate that information provided to the stakeholders should consider the shareholders' expectations and the needs for assessing the companies' reporting performance. In this respect, the present research is concerned with the best practice of risk reporting based on the validation of stakeholders' coalition using a Delphi technique. This study believes the technique is consistent with the four steps proposed by Jurgens et al. (2010). The following section elaborates on the utilization of the technique in measuring NFRD.

\section{DEVELOPMENT OF NON-FINANCIAL RISK DISCLOSURE INDEX}

This study assumes that annual reports are considered a primary reporting mechanism for disclosing risk information to the stakeholders (Bisson 2018; Gray, Kouhy, \& Lavers 1995). Although most previous studies utilize narrative content analysis on the annual reports to measure risk disclosure, the current study develops the NFRDI and its application in the study of the annual reports of Malaysian-listed companies. The Delphi technique is chosen to construct the index as this technique is based on the perspective of the selected experts on a specific area and does not rely on historical data. The technique mainly aims to gain reliable consensus from a group of experts that make a judgment on a set of issues (Okoli \& Pawlowski 2004). The Rand Corporation in the United States military intelligence branch first established this first methodology in 1948 (Hefferan \& Wardner 2012). Since then, this methodology has been used to a wide range of fields but frequently used in corporate accounting reporting. Flostrand, Pitt, and Bridson (2020) reviewed over 2,637 studies that applied the Delphi technique and found that over a 42-year period from 1975 to 2017, only 175 studies $(6.6 \%)$ were on business fields and 116 $(4.3 \%)$ on other social science and law. Given that small numbers of studies in business and social science fields still exist, the present research aims to further promote the use of the technique in corporate reporting specifically risk reporting. This method involves not only collection of views from panel experts via series of rounds of questioning and verification on the response (Hefferan \& Wardner 2012), but also removal of biases which may arise by maintaining the anonymity of the panel (Flostrand et al. 2020). Having the panel valuable views and responses would help in understanding the issues we are dealing with. Theory and research are said generated from the practical world, which is from the practice of the experts in the field (Dobratz, 2003). Therefore, the technique is the most suitable approach that offers advantages to the study of NFRD matters. 
Furthermore, the experts for this study are mostly the stakeholders of companies which provide a consensus on the NFRI that should be disclosed by Malaysian companies. Therefore, the technique aims to be consistent with Jurgens et al. (2010) and Denning (2019) argument for companies to involve all stakeholders so coalition strategic decision making will be made.

\section{CRAFTING OF THE NFRDI VIA A DELPHI TECHNIQUEC ${ }^{1}$}

A disclosure index in accordance with Coy and Dixon (2004) and Sahari (2017) is developed to achieve the research objective. There are six steps to the index formation process (Coy \& Dixon 2004). The first two phases provide a summary of the reporting purpose and an examination of contemporary interest. As for the current report, the purpose of NFRD and the literature review of risk disclosure are addressed in the previous section. Discussions of the last four (4) steps are as follows. The NFRDI is also constructed partly in line with Jurgens et al.'s (2010) steps to incorporate the stakeholders view in corporate strategic decision making:

\section{DETERMINE THE OBJECTIVE OF CONSTRUCTING THE INDEX.}

The objective of crafting the NFRDI is to identify the necessary risk information to be disclosed in the annual report to ensure that the common items in the index are based on the consensus of the stakeholders.

\section{IDENTIFY APPROPRIATE NON-FINANCIAL RISK ITEMS AND CATEGORIES.}

Developing the index comes with three stages: (1) identification of potential items, (2) identification of Delphi panelist, and (3) development of the final index using the Delphi technique. The initial list of 76 NFRI is derived from prior studies, such as Tan et al. (2017), Abdullah et al. (2015), Ntim et al. (2013), Miihkinen (2012), and Linsley and Shrives (2006). There were initially eight (8) categories of NFRI which are operations risk (22 items), empowerment risk (7 items), technology and information processing risk (4 items), integrity risk ( 3 items), strategic risk (26 items), damage and hazard risk ( 3 items), research and development risk (3 items) and risk management governance ( 8 items). Out of the 76 items, 12 items are eliminated during the validity test due to redundancy and non-risk-related items. In addition, new items are included as suggested by the panels and modification of the ambiguous terms for several items adapted from past literature. For example, item "integrity" under the information technology and processing category adapted from Linsley and Shrives (2006) has been changed to "System's safety/security" to avoid confusion with the integrity risk category. Therefore, 64 final items included in the questionnaire (checklist) are utilized in the third and fourth steps. Appendix A presents list of non-financial categories and items from past literature and new items suggested by the panels.

\section{DELPHI PANELISTS}

The role of Delphi panelists is significant for this study as they will influence the outcome of the study. Therefore, individuals are considered qualified to be the Delphi panelits if they have some related context and experience with the target question, are able to provide helpful feedback, and are willing to update their initial or previous decisions with a view to achieving or reaching a consensus (Pill 1971; Hsu \& Sandford 2007). In this study, the Delphi's panelists are the stakeholders, which are experts or well versed in risk management, to ensure that the NFRDI is an outcome of all stakeholders' input. They are knowledgeable about various issues related to the subject, have relevant experience, and are an individual among stakeholders (Loo 2002). Initially, 27 experts were invited to participate in the Delphi technique. Twelve are research analysts of research companies licensed as Investment Advisors under the Capital Market Securities Act 2007, registered as the Bursa Research Scheme participants. Seven are from the GLC and eight are academicians and investors. However, out of 27, only 12 agree to participate as panelists in this technique. Nevertheless, one of the panelists withdraws after the first round of the technique. In a peer-reviewed research by Rowe and Wright (1999), the scale of Delphi panels ranged from a low of three (3) members to a high of 80 members. However, as most studies involve between eight (8) to 16 panels, a minimum of eight (8) are suggested (Hallowell \& Gambatese 2010). Thus, a total of 11 panelists is appropriate for this study. Table 1 reports details of the panelists. Out of 11 panelists, four (4) members are chief risk officer from represent government-linked, government-linked investment, and listed companies. One (1) panel member represents a nongovernment organization that protects shareholder interest while one (1) panel is a Director of Centre of Risk Management, sustainability \& occupational health in government sector. The balance five (5) are academician who are experts in corporate reporting, risk management and risk disclosure from public and private universities. The roles of the panel are to validate the items included in the checklist (Hooks, Tooley, \& Basnan 2015) and assess the importance of the items to be disclosed in the annual reports. The panelists must remain involved in the process until they reach an agreement to ensure consistency in the opinion. 
TABLE 1. Details of Delphi panelists

\begin{tabular}{llc}
\hline \multicolumn{1}{c}{ Role } & \multicolumn{1}{c}{ Description } & $\begin{array}{c}\text { Number of } \\
\text { panels }\end{array}$ \\
\hline $\begin{array}{l}\text { Chief Risk Officer / } \\
\text { Director }\end{array}$ & $\begin{array}{l}\text { Currently holding a position as Director of risk department, chief risk } \\
\text { officer in a government Linked Companies, Government Linked- } \\
\text { Investment Companies, listed companies. Having experience as in } \\
\text { the risk department for more than 5 years. }\end{array}$ & 4 \\
$\begin{array}{l}\text { Non- profit } \\
\text { organisation }\end{array}$ & $\begin{array}{l}\text { Representative from NGO involves in protecting the interest of } \\
\text { shareholders. }\end{array}$ & 1 \\
$\begin{array}{l}\text { Government } \\
\text { representative }\end{array}$ & $\begin{array}{l}\text { Director of Centre of Risk Management, sustainability \& } \\
\text { occupational health }\end{array}$ & 1 \\
Academician & $\begin{array}{l}\text { Having background of research in corporate reporting, risk } \\
\text { management, risk disclosure and teaching courses related with risk } \\
\text { and finance from research universities, public and private } \\
\text { universities. }\end{array}$ & 5 \\
\hline \multicolumn{2}{l}{} \\
\hline
\end{tabular}

\section{CONSTRUCTING THE NFRDI}

This stage is important, where the study utilizes a Delphi technique to seek consensus among the panelists on the NFRI to be disclosed by Malaysian companies. The Delphi technique is one of the most popular techniques for obtaining ideas or decisions on a topic of discussion based on expert opinions in the field of study (Coy \& Dixon 2004). The technique involves several rounds until an agreement is obtained. At each round, panelists can use their judgment to consider or reconsider their views and provide new ideas or suggestions on the checklist for the development of the index (Coy \& Dixon 2004). The number of rounds depends on the attainment of the agreement among the panelists and their cooperation to remain in the group (Coy \& Dixon, 2004). The form of response captured the panelists' perceptions of the importance of each item. For this study, the entire Delphi technique took four (4) months and three rounds to complete after the panelists have reached their consensus (Habibi, Sarafazi \& Izadyar 2014).

Comparing to other methods, issue on validity of the research findings through the Delphi method is minimum. In this method, Landeta (2006) identify approximately five metrics were present to deduce the inherent consistency of the methodology. The metrics are i) the consistency and reliability of the panel of experts, ii) the period between rounds, iii) the expert statements, iv) the reliability of the findings between rounds and $v$ ) the agreement of the opinion. Therefore, consistent with Landeta (2006), it is believed the issue of validity and reliability in this study have been addressed. Specifically, a) all of the panelists have participated from the beginning until the end of the Delphi exercise, $b$ ) the time between rounds is less than one and a half months, c) the panelits offered high quality information and recommendations, d) there were quite a few improvements in the second round as opposed to the first round, and finally, e) the consensus was reached in the third round.

\section{FINDINGS}

\section{NFRI AND NFRDI}

In the first round, the panelists suggested 18 additional items to be included in the index. These additional items are included in the questionnaires for the second round, totaling to 82 items. In the following rounds, all panelists can reconsider their initial response. An analysis of mean and standard deviation is performed for each item, which is then compared to determine the level of consensus among panelists. The analysis indicates that nearly half of the standard deviation of the items was either unchanged or lower than the previous round. At the end of round three, a stable consensus is achieved, and the Delphi technique is considered complete. Therefore, the final items to be listed as NFRD are still 82 items (Table 2), which were further analyzed to determine their level of importance. 
TABLE 2. Final list of non-financial risk items suggested by the experts

\begin{tabular}{|c|c|}
\hline Type of Non-financial risk & Item \\
\hline \multirow[t]{23}{*}{ Operational } & Key person dependence risk \\
\hline & Uncommon business fluctuations in demand \\
\hline & Interruptions in the delivery chain \\
\hline & Price fluctuations of the factors of production \\
\hline & Patents and other industrial rights \\
\hline & Customer satisfaction \\
\hline & Reputation and brand name erosion \\
\hline & Stock obsolescence and shrinkage \\
\hline & Product and service failure \\
\hline & Environmental issues/impact \\
\hline & Health and Safety \\
\hline & Unsuccessful project deliveries \\
\hline & Quality control \\
\hline & Product development \\
\hline & Business process and procedure \\
\hline & Sourcing \\
\hline & Compliance on operations regulations \\
\hline & Social contribution / community support \\
\hline & Delay in delegation of authority* \\
\hline & Imprecise strategic planning process* \\
\hline & Ineffective business continuity management* \\
\hline & Changes in the market and competition* \\
\hline & Loss of demand for assets and services* \\
\hline \multirow[t]{11}{*}{ Empowerment } & Governance, leadership, and Management \\
\hline & Outsourcing \\
\hline & Performance incentives \\
\hline & Resistance to change/ adaption/Change readiness \\
\hline & Communications \\
\hline & High employee turnover rate \\
\hline & Productivity of staff \\
\hline & Non-information of employee's position in relation to the decision-making \\
\hline & scoped issues* \\
\hline & Absences of governance framework and limits authority* \\
\hline & Lack of succession planning* \\
\hline \multirow{4}{*}{$\begin{array}{l}\text { Information Processing and } \\
\text { Technology }\end{array}$} & System' safety and security (Integrity) \\
\hline & Accessibility by unauthorized personnel \\
\hline & Infrastructure \\
\hline & Cybercrime\# \\
\hline \multirow[t]{10}{*}{ Integrity } & Management and employee fraud / illegal acts \\
\hline & Reputation \\
\hline & Conflict of interest\# \\
\hline & Evasion or avoidance of tax regulation\# \\
\hline & Market manipulation activities\# \\
\hline & Lack of transparency on supplier or tender's selection process* \\
\hline & Recruitment and promotion* \\
\hline & Vendor management* \\
\hline & Whistle blowing policy* \\
\hline & Governance of subsidiaries companies* \\
\hline \multirow[t]{10}{*}{ Strategy } & Market competition \\
\hline & Market Area \\
\hline & Position in the production chain \\
\hline & Too dependence on customer \\
\hline & Too dependence on suppliers \\
\hline & Changes in technological progress \\
\hline & Regulatory changes \\
\hline & Political changes \\
\hline & Economical changes \\
\hline & Mergers and acquisitions \\
\hline
\end{tabular}




\begin{tabular}{ll}
\hline & Pricing \\
Industry specific changes \\
Launching of new products \\
Business portfolio changes \\
Business life cycle \\
Changes in management team (Management) \\
Competitors presence \\
Valuation of asset, liabilities, and stock \\
Strategic planning process (Planning) \\
Performance measurement \\
Taxation policy changes \\
GDP growth/ market demand/ aggregate demand \\
Inflation rate changes \\
Budget deficit \\
Company's plan on new products or services \\
Incompleteness of going Research and Development projects \\
Breach of trust on Research and Development's confidentiality \\
Developing products / services that turn out to be not commercially \\
successful* \\
The new developed products / services turn out to be costly to produce* \\
Unethical research* \\
Conflict of interest among funder* \\
Incompetent of researches* \\
Significant illegal actions \\
Natural disasters and/or terrorism \\
\hline Damage and Hazard ${ }^{*}$ Suggested by panelists in Round 1, and ${ }^{*}$ Suggested by Pre-test Panelists \\
\hline
\end{tabular}

Table 3 shows the frequency of risk categories within the level of importance. All items fall either as moderately important or very important. Out of the seven categories, all five items in information processing and technology risk, and damage and hazard risk categories are identified very important to be disclosed in the annual report. All items under research and development risk were rated moderately important, and the other categories of items are either rated moderately important or very important. However, all items (8) of the research and development category are excluded from the final list because all experts classified them as moderately important to be disclosed in the annual reports. This study further found that out of 64 items initially identified in prior studies, only 26 items $(40.6 \%)$ are considered by the panelists as very important and relevant to be published in the annual report.

TABLE 3. Frequency of risk categories within degree of disclosure importance

\begin{tabular}{lcccccc}
\hline \multicolumn{1}{c}{ Risk Category } & \multicolumn{3}{c}{ Frequency of Items within level of } & Total items \\
importance & 0 & 1 & 2 & 3 & 4 & \\
\hline Operational Risk & 0 & 0 & 17 & 6 & 0 & 23 \\
Empowerment Risks & 0 & 0 & 9 & 1 & 0 & 10 \\
Information Processing and Technology & 0 & 0 & 0 & 5 & 0 & 5 \\
Risks & 0 & 0 & 4 & 6 & 0 & 10 \\
Integrity Risks & 0 & 0 & 15 & 9 & 0 & 24 \\
Strategic Risks & 0 & 0 & 8 & 0 & 0 & 8 \\
Research and Development Risks & 0 & 0 & 0 & 2 & 0 & 2 \\
Damage and Hazard Risks & 0 & 0 & 53 & 29 & 0 & 82
\end{tabular}

Notes: Based on the 5-point importance ranking scale. $0=$ Not Important, $1=$ slightly important, $2=$ moderately important, 3= Very important, 4= Extremely important.

Table 4 shows a ranking score for risk items identified as very important items to be disclosed in the annual report. The items are ranked according to the mean score of importance. As the 29 items are perceived as very important to be 
disclosed in the annual reports, the items are finalised as the components for the NFRDI. Of these finalised items, 26 were known from previous study, while three (3) additional items (cybercrime, conflict of interest and market manipulation) were suggested by the experts. Table 5 presents NFRDI and its components. Column 2, the last row of Table 5 , indicates the number of risk items for each category in the index (29) over the number of items in previous studies (64) and suggested by the panelists (18). The finding indicates that only 35\% (29/82) of the NFR items are considered important, which reflects some gaps between prior studies and the stakeholders (experts). Table 5 also indicates that six NFR categories are finalised to form the NFRDI. None of the research and development risks category is rated as very important, thus not represented in the NFRDI. The finding reflects the insignificant risks among the stakeholders.

TABLE 4. Ranking score for risk item

\begin{tabular}{lc}
\hline \multicolumn{1}{c}{ Risk Item } & Mean (Max 4) \\
\hline Governance, Leadership, and management & 3.45 \\
Cybercrime & 3.45 \\
Market competition & 3.45 \\
Health and safety issues & 3.36 \\
System's security / safety & 3.36 \\
Reputation / Misleading information & 3.36 \\
Significant illegal actions & 3.36 \\
Environmental impact & 3.27 \\
Compliance on operations regulation & 3.27 \\
Changes in technological development & 3.27 \\
Regulatory changes & 3.27 \\
Whistle blowing policy & 3.18 \\
Natural disasters/terrorism & 3.18 \\
Price fluctuations of the factors of production & 3.09 \\
Availability of information & 3.09 \\
Infrastructure & 3.09 \\
Management and employee illegal's act & 3.09 \\
Conflict of interest & 3.09 \\
Market areas & 3.09 \\
Economical changes & 3.09 \\
Business portfolio changes & 3.09 \\
Changes in management team & 3.09 \\
Key person dependence risk & 3.09 \\
Product and service failure & 3.00 \\
Accessibility by unauthorized personnel & 3.00 \\
Market manipulation activities & 3.00 \\
Governance of subsidiaries companies & 3.00 \\
Political changes & 3.00 \\
Industry specific changes & 3.00 \\
\hline
\end{tabular}


TABLE 5. NFRDI and its components

\begin{tabular}{|c|c|c|c|c|}
\hline No. & Risk Category & Risk Items & Score & NFRDI \\
\hline \multirow[t]{6}{*}{1.} & Operating & Compliance on operations regulation & 1 & \\
\hline & & Environmental impact & 1 & \\
\hline & & Health and safety issues & 1 & \\
\hline & & Key person dependence risk & 1 & \\
\hline & & Product and service failure & 1 & \\
\hline & & Price fluctuations of the factors of production & 1 & 6 \\
\hline 2. & Empowerment & Governance, Leadership, and management & 1 & 1 \\
\hline \multirow[t]{5}{*}{3.} & Information processing & Accessibility by unauthorized personnel & 1 & \\
\hline & and technology & Availability of information & 1 & \\
\hline & & Cybercrime & 1 & \\
\hline & & Infrastructure & 1 & \\
\hline & & System's security / safety & 1 & 5 \\
\hline \multirow[t]{6}{*}{4} & Integrity & Conflict of interest & 1 & \\
\hline & & Governance of subsidiaries companies* & 1 & \\
\hline & & Management and employee illegal's act & & \\
\hline & & Market manipulation activities & & \\
\hline & & Reputation / Misleading information ${ }^{\#}$ & & \\
\hline & & Whistleblowing policy* & 1 & 6 \\
\hline \multirow[t]{9}{*}{5.} & Strategy & Business portfolio changes* & 1 & \\
\hline & & Changes in management team & 1 & \\
\hline & & Changes in technological development ${ }^{\#}$ & 1 & \\
\hline & & Economical changes & 1 & \\
\hline & & Industry specific changes & 1 & \\
\hline & & Market areas & 1 & \\
\hline & & Market competition & 1 & \\
\hline & & Political changes & 1 & \\
\hline & & Regulatory changes & 1 & 9 \\
\hline \multirow[t]{3}{*}{6.} & Damage and Hazard & Natural disasters/terrorism & 1 & \\
\hline & & Significant illegal actions & 1 & 2 \\
\hline & Maximum Score of NF & I & & 29 \\
\hline
\end{tabular}

\section{EXTENT OF NFRD AMONG THE MALAYSIAN-LISTED COMPANIES}

\section{SAMPLE}

This study used listed companies in Bursa Malaysia (Malaysia Stock Exchange) as a sample. Bursa Malaysia has 800 companies; however, a total of 52 finance companies were removed from the list. Consistent with prior studies, companies in the financial industry are excluded as they are subject to different and specific legal requirements (Barros, Boubaker \& Hamrouni, 2013). Neuman (2014) suggested a 54.3\% sample for a population of 1,000. However, Li, Pike and Haniffa (2008) stated that a sample size of $31 \%$ of the population is efficient for a content analysis study. Nevertheless, the sample size was increased to $50 \%$ from the balance of 748 companies. The 374 companies are selected with a sampling interval of two. The sample size is consistent with Abdullah et al. (2015). Furthermore, 61 companies are eliminated due to unavailable annual reports, which bring the final sample to 313 companies. Hence, the final observation for the 2016-2018 period is 939 firm-year.

\section{MEASURING NFRD}

Consistent with Barros et al. (2013), the presence of NFRD is identified in four sections of the narrative part in the annual report. The sections are Chairman's Statement and Management Discussion and Analysis, which are in line with Abdullah et al. (2015) and Amran, Rosli and Che Haat (2009). The other two are Sustainability Statement and Statement of Risk Management and Internal Control sections as companies disclose NFR in these sections. All disclosed items are considered equally important to avoid subjectivity, whereas the content on the information of each NFR item may vary from one company to another.

The extent of the NFRD in the annual report is measured based on a dichotomous score, that is, 1 for NFR items related to the risk category and 0 if otherwise. Cooke (1991) noted that the dichotomous approach is objective because it focuses on the absence and presence of the items in the annual report and is consistent with prior studies, such as Sahari 
(2017) and Li et al. (2008). Consistent to Abdullah et al. (2015), scores are assigned to sentences that explain the existence of the respective risks and any proposed actions to overcome the said risks.

Scoring requires the researcher to identify the appropriate keyword for searching the risk items. For example, the information related to key person dependence risk was disclosed in the Management Discussion and Analysis section. The identification of the risk is based on a keyword key person dependence risk. In this case, the statement ".... A loss, without a suitable replacement in a timely manner could affect the Group's ability to remain competitive in the industry," indicates the risk of the company to remain competitive in the industry if the company fails to replace the key person, such as directors and key management personnel, on an appropriate time. Therefore, a score of 1 is allocated to the company. Twenty annual reports from various industries were re-visited approximately 3 months after the first attempt to achieve stability of this kind of data, which is consistent with Milne and Adler (1999). Krippendorff's alpha test was used to estimate the inter-coder reliability (Hayes \& Krippendorff, 2007). The results indicate high inter-coder reliability as the inter-coder reliability is $\alpha=$ 0.8234 with an alpha above 0.80 .

The total score of each risk category is computed as the unweighted sum of the score of all items in the index (Table 4). Accordingly, the level of the NFRDI for each company is determined as below:

$N F R D I=\frac{\text { Actual Score of NFRD }}{\text { Maximum Score of NFRD }}$

Where,

NFRDI $=$ Non-financial risk disclosure index.

NFRD $=$ Non-financial risk disclosure.

\section{DESCRIPTIVE ANALYSIS OF DISCLOSURE FREQUENCIES}

Table 6 shows the descriptive statistic for each category of NFRD. The results show an increasing trend in the level of disclosure from 2016 to 2018. On average, the level of NFRD for sample companies has shown an increasing trend by $26.9 \%$ in 2018 compared with 2016. Comparing the risk categories, Integrity risk has shown a 114\% increase in the level of disclosure compared with the other risk categories, followed by Operating risk with a $76.2 \%$ increase (21\% in 2016 to $37 \%$ in 2018). This finding indicates that issues on integrity risk have become a major concern among companies as the risk will affect their reputation of the stakeholders. Our study also indicates that none of the companies disclosed risk related to Governance of subsidiaries companies (Table 7).

The results also indicate that the most common category for NFRD among sample companies is Empowerment risk (2016: 33\%, 2017: 42\%, 2018: 48\%), and followed by Operating risk (2016: 21\%, 2017: 27\%, 2018: 37\%). These results indicate that the sample companies disclosed more Empowerment risk information and Operating risk information than other categories. This finding contradicts to risk reporting frequencies reported by Abdullah et al. (2015). They found that operational and strategic risks were the two highest risks reported. However, different from the current study, Abdullah et al. (2015) used the number of sentences to measure the level of disclosure. In this regard management might have detail unconfidential operating risk information to disclose to the stakeholders as compare to empowerment risk. Therefore, whether these comparative results are due to management discretion of providing or not providing enough information or unwillingness to disclose such risk to the stakeholders is unclear (Shivaani et al., 2020). The lowest risk disclosure category is Information processing and technology risk with a mean score of 1\% (2016), 4\% (2017), and 5\% (2018). Although the mean is low, the descriptive analysis shows that the disclosure level of Information processing and technology risk increases from $40 \%$ (2016) to $80 \%$ (2018). This result shows that companies are very concerned with the risk related to threats and security in daily operations. This also might be due to the change in communication where information technology helps companies to disseminate relevant information to their stakeholders. 
TABLE 6. Descriptive statistic for each risk category $(n=313)$

\begin{tabular}{lcccc}
\hline \multicolumn{1}{c}{ Risk Categories } & Year & Mean & Min & Max \\
\hline Operating & 2016 & 0.21 & 0.00 & 0.83 \\
& 2017 & 0.27 & 0.00 & 0.83 \\
\hline Empowerment & 2018 & 0.37 & 0.00 & 0.83 \\
\hline Information processing and & 2016 & 0.33 & 0.00 & 1.00 \\
Technology & 2017 & 0.42 & 0.00 & 1.00 \\
& 2018 & 0.48 & 0.00 & 1.00 \\
\hline Integrity & 2016 & 0.01 & 0.00 & 0.40 \\
& 2017 & 0.04 & 0.00 & 0.80 \\
& 2018 & 0.05 & 0.00 & 0.80 \\
\hline Strategy & 2016 & 0.07 & 0.00 & 0.67 \\
& 2017 & 0.10 & 0.00 & 0.50 \\
& 2018 & 0.15 & 0.00 & 0.67 \\
\hline Damage and Hazard & 2016 & 0.19 & 0.00 & 0.78 \\
& 2017 & 0.23 & 0.00 & 0.67 \\
& 2018 & 0.26 & 0.00 & 0.78 \\
\hline Overall Categories & 2016 & 0.06 & 0.00 & 1.00 \\
& 2017 & 0.08 & 0.00 & 1.00 \\
& 2018 & 0.09 & 0.00 & 1.00 \\
\hline
\end{tabular}

\section{STAKEHOLDERS’ EXPECTATIONS AND THE REALITY OF NFRD}

Table 7 presents the discrepancy between the actual percentages of each item disclosed in the annual report and the panelist perceived important NFR information. The results indicate that despite a high mean score on the perceived importance of the Information processing and technology category to be disclosed in the annual reports, the level of disclosure of each item is very low. Each item is found to be disclosed at the level between $0 \%$ and $13 \%$ within the period of observation. The highest score is 12\%, which is observed in 2018 for the System's security and safety item. This finding is consistent with Abdullah et al. (2015) who reported Technology and information processing disclosure to be the lowest.

Table 7 indicates the level of overall NFRD categories has significantly increased from 2016 to 2018. The extreme increase can be observed in this category, with the range of percentage increase in disclosure from $567 \%$ to infinity $(\infty)$. One of the items, that is, Cybercrime, has been reported an infinity increase from $0 \%$ in 2016 to $6 \%$ in 2018 . Although the level of disclosure is still low, the increase in disclosure is consistent with the perception of the expert. Cybercrime, one of the three (3) items, was ranked as very important (the highest mean 3.45), followed by System's security/safety has shown an increase from $0.6 \%$ in 2016 to $12 \%$ in 2018 (1,900\% increase).

Table 7 also indicates a consistent increase in the level of risk disclosure from 2016 to 2018 in the Strategy risk category. The disclosure level of strategy risk items shows an increase in the range from $114 \%$ to $592 \%$. However, although risk item Market competition has been ranked with the highest mean score by the Delphi experts (3.45), the level of disclosure for this item increased by $364 \%$. Nevertheless, on average, the level of Market competition disclosure in 2018 is $58 \%$, which is the second highest after the environmental impact (73\%). Table 7 shows a significant improvement for Environmental impact compared to the $28.1 \%$ disclosure level recorded in 2016. This result might be because companies are subject to several regulations, such as Environmental Quality (Clean Air) Regulations 2014 for emissions of air pollutants, and requirements held by the Department of Environment for waste management. Information related to Price fluctuations of the factors of production is consistently reported at above $45 \%$. This result is mainly affected by weak in Ringgit Malaysia and the global economy in which the group of the companies operated. The only item for the Empowerment category has shown a consistent performance on the level of disclosure. The high level of disclosure is consistent with the high mean score on the perceived importance of the item rated by the panelists. The consistency is undeniable as good corporate governance practices and leadership are important for the success of the company. 
TABLE 7. Experts' perceived scores and the practice of NFRD

\begin{tabular}{|c|c|c|c|c|c|c|}
\hline \multirow{2}{*}{ Risk Categories } & \multirow{2}{*}{ Items } & \multirow{2}{*}{$\begin{array}{l}\text { Mean score } \\
\text { perceived } \\
\text { important }\end{array}$} & \multicolumn{3}{|c|}{ Percentage of disclosure (\%) } & \multirow{2}{*}{$\begin{array}{c}\text { Percentage of } \\
\text { increase from } \\
2016 \text { to } 2018 \\
(\%)\end{array}$} \\
\hline & & & 2016 & 2017 & 2018 & \\
\hline \multirow[t]{6}{*}{ Operating } & Compliance on operations regulation & 3.27 & 14.40 & 17.30 & 21.00 & 45.83 \\
\hline & Environmental impact & 3.27 & 28.10 & 46.30 & 73.00 & 159.79 \\
\hline & Health and safety issues & 3.36 & 23.00 & 35.10 & 51.00 & 121.74 \\
\hline & Key person dependence risk & 3.09 & 3.80 & 7.30 & 6.00 & 57.89 \\
\hline & Product and service failure & 3.00 & 10.50 & 7.70 & 16.00 & 52.38 \\
\hline & $\begin{array}{l}\text { Price fluctuations of the factors of } \\
\text { production }\end{array}$ & 3.09 & 44.70 & 51.80 & 53.00 & 18.56 \\
\hline Empowerment & $\begin{array}{l}\text { Governance, Leadership, and } \\
\text { management }\end{array}$ & 3.45 & 32.30 & 42.00 & 50.00 & 54.80 \\
\hline \multirow{5}{*}{$\begin{array}{l}\text { Information } \\
\text { processing and } \\
\text { technology }\end{array}$} & $\begin{array}{l}\text { Accessibility by unauthorized } \\
\text { personnel }\end{array}$ & 3.00 & 0.30 & 2.00 & 2.00 & 567.67 \\
\hline & Availability of information & 3.09 & 0.30 & 1.00 & 3.00 & 900.00 \\
\hline & Cybercrime & 3.45 & 0.00 & 7.00 & 6.00 & $\infty$ \\
\hline & Infrastructure & 3.09 & 0.30 & 2.00 & 2.00 & 567.67 \\
\hline & System's security / safety & 3.36 & 0.60 & 7.00 & 12.00 & $1,900.00$ \\
\hline \multirow[t]{6}{*}{ Integrity } & Conflict of interest & 3.09 & 0.30 & 1.00 & 1.00 & 233.33 \\
\hline & Governance of subsidiaries companies & 3.00 & 0.00 & 0.00 & 0.00 & - \\
\hline & Management and employee illegal's act & 3.09 & 3.50 & 11.00 & 16.00 & 357.14 \\
\hline & Market manipulation activities & 3.00 & 0.90 & 3.00 & 2.00 & 122.22 \\
\hline & Reputation / Misleading information & 3.36 & 6.40 & 27.00 & 31.00 & 384.38 \\
\hline & Whistle blowing policy & 3.18 & 4.50 & 19.00 & 37.00 & 722.22 \\
\hline \multirow[t]{9}{*}{ Strategy } & Business portfolio changes & 3.09 & 3.00 & 6.00 & 7.00 & 133.33 \\
\hline & Changes in management team & 3.09 & 0.30 & 1.00 & 1.00 & 233.33 \\
\hline & Changes in technological development & 3.27 & 2.60 & 14.00 & 18.00 & 592.31 \\
\hline & Economical changes & 3.09 & 10.80 & 35.00 & 48.00 & 344.44 \\
\hline & Industry specific changes & 3.00 & 4.20 & 7.00 & 9.00 & 114.26 \\
\hline & Market areas & & 1.90 & 10.00 & 9.00 & 373.68 \\
\hline & Market competition & 3.45 & 12.50 & 55.00 & 58.00 & 364.00 \\
\hline & Political changes & 3.00 & 6.07 & 22.00 & 32.00 & 427.18 \\
\hline & Regulatory changes & 3.27 & 15.00 & 54.00 & 55.00 & 266.67 \\
\hline Damage and & Natural disasters/ terrorism & 3.18 & 1.90 & 10.00 & 12.00 & 531.57 \\
\hline Hazard & Significant illegal actions & 3.36 & 1.60 & 6.00 & 5.00 & 212.50 \\
\hline
\end{tabular}

Within the Integrity category, two items, namely, Reputation/misleading information and Whistleblowing policy, are reported with a substantial increase in disclosure level from 2016 to 2018. Whistleblowing policy has increased by $722 \%$ from $4.5 \%$ in 2016 to $37 \%$ in 2018 . This item is suggested to be disclosed in the annual report by the panelists, followed by the $384 \%$ increase in disclosure of Reputation/misleading information from $6.4 \%$ (2016) to $31 \%$ (2018). Although many companies may recently establish their whistleblowing policy to curb issues related to integrity, the companies seem to voluntarily disclose the numbers of cases in the annual reports. This event is because companies are taking serious actions on the policies' implementation.

\section{DISCUSSION}

This study developed a validated instrument to assess the transparency of NFRD of Malaysian-listed non-financial companies based on stakeholder theory. Findings from this study indicate that 29 non-financial risk items are considered very important to be disclosed in the annual report of the companies. These items are related to operational, empowerment, information processing and technology, integrity, strategic, and damage and hazard risks, which formed the NFRDI. Observation from 2016 to 2018 reveals that the level of NFRD is still low, but with some significant increase in some of the NFRD items. However, the level of disclosure is inconsistent with what the stakeholders perceived important to be disclosed in the annual report. The NFRDI application is believed to promote additional transparent information relevant to stakeholders' decision making, particularly in developing countries. The present study finds a gap between prior studies and the stakeholders' (experts) needs (reported in this study) on the relevance of NFR for decision making. Out of the 64 items suggested, only 26 items are important, and three more items (cybercrime, conflict of interest, and market manipulation 
activities) are new items which were suggested by the expert. According to the panelists, cybercrime issues, such as hacktivism, malware, and online piracy, are topical issue specifically within the current industry 4.0 scenario, particularly in the developing countries, where their companies tend to acquire locally manufactured security software that is cheaper but insecure in technologies (Kshetri, 2013). According to Kshetri (2013) this event is due to the top security software companies generally focus their business on industrialized countries.

Conflict of interest is a topical concern as it emerges in any business relationship. Conflict of interest arises when a party's action exceeds the general duties that should be performed in good faith. Bahar and Thevenoz (2007) explained that disclosing the conflict of interest matters has benefited the regulators because disclosure may be used to overcome any information asymmetry among the parties involved. Manipulated activities normally deals with human acts by using distortive market price, fraud, and misinformation (Lin, 2016). These activities will have an impact on not only the investment and capital distribution specifically in one marketplace but also another marketplace. However, Kaplan and Mikes (2012) stated that such behavior is controllable and ought to be eliminated or avoided. This risk should be managed through prevention and can be disclosed and defended through guidelines that clarify the company's goals and values (Kaplan \& Mikes 2012). Therefore, disclosure of conflict of interest can be made in the statement on the company's goals and values, but in a voluntary setting, disclosing such items depends on the manager's discretion. However, through the Delphi technique, the present study discovers several non-financial items that seem fascinating among the stakeholders (panelists). Companies are regarded as credible if they disclose many risks information (Jia et al. 2016). In other words, they are aware of the threats and would develop strategies to mitigate risk and ensure sustainability (Jia et al. 2016). This study also found that the balance of thirty-eight (38) items from previous studies was consistently had been voted at rank 2 and below in rounds 2 and 3 of the Delphi technique. Based on the panelists' justification, shareholders would treat those items either as extremely confidential, the business process that may leads to reputational issues, or not relevant to them.

\section{CONCLUSIONS AND RESEARCH CONTRIBUTION}

This study reveals some gaps on the NFRD between the current study and prior studies and between the experts' views and the actual disclosure by the companies. The Delphi technique allows us to identify some differences between prior studies and the current study on the relevant NFR items to be disclosed in the annual reports. This study is consistent with the current view of the business to serve all stakeholders and engage multiple stakeholders in the management strategic driver. We believe that our NFRDI is more comprehensive as it was developed based on the views of a group of stakeholders who are experts in risk management compared with the view of an individual researcher. Although prior studies and experts' opinions lead us to identify 82 items, the current study reduces the numbers into 29 very important items that are recommended to be disclosed in the annual reports. However, the content analysis on the annual reports of Malaysian-listed non-financial companies indicates that the level of risk disclosure is still low for some risk items. Nevertheless, some aggressive improvement was observed from 2016 to 2018. This event indicates these companies value the significance of NFRI, justifying the increase in the level of disclosure. Overall, the findings of the current study are consistent with the stakeholder theory approached by Jurgens et al. (2010) which recognised the need for NFR disclosure by stakeholders.

This study provides a significant contribution to the literature in terms of NFRDI which was crafted based on the Delphi technique. The technique is foreign in accounting research but is commonly been used in management, education, health, and science research. This approach extends the previous Malaysian studies by focusing on identifying the perceived important risk information based on the consensus of multiple stakeholders, which has been ignored in most prior studies. This study believes that the index will help companies to disclose additional relevant NFRI that is not only less costly but also relevant to the multiple stakeholders' decision making. The index also may help regulators in their monitoring as it was developed based on the views of Malaysian stakeholders. Moreover, the risk components are less than what was proposed in previous studies which can reduce monitoring time and cost.

Findings from this study might be subject to several limitations. First, this study acknowledges that some subjectivity was involved during the development of the NFRDI, particularly related to the decision on the introduction and elimination of risk items. However, the Delphi technique might reduce some of the concerns. Second, this study utilises the content analysis approach which consumes time and effort to identify and rate the score for each annual report of the company to identify the level of NFRD. Third, some judgments are also involved during the content analysis exercises as these open for human error due to unintentionally wrong decision, coding, or typo error during the scoring process. However, several precaution measures were taken, such as the reliability test to ensure that the scores obtained from the content analysis are consistent through-out the entire process.

Future research might extend the Delphi technique by including other experts to represent other groups of stakeholders, such as auditors, financial advisors, and investors. Future research can also extend the Delphi technique and content analysis for a long period to ensure ample time for the experts to better understand the other experts' views. Comparison can be done on not only the extent of disclosure but also any differences in the stakeholders' perceptions specifically between the non-financial and financial companies considering that these firms are subject to different regulations and acts. Thus, the differences in risks that are faced by these companies are worth understanding. Furthermore, 
the Delphi technique may be performed in cross-country studies for additional representative NFRDI which allows for comparative study across countries (e.g., Asian countries), culture, and economics. Future research might also want to investigate the positive and negative types of NFRD in the annual reports because different types of voluntary NFRD might have various impacts on the company's performance.

\section{ACKNOWLEDGMENT}

The authors wish to thank participants of the 14 Malaysian National Economics Conference 2019 for their comments and input, Center of Innovation and Technology Transfer, UKM for the assistance in copyright registration, and Financial assistance from Universiti Kebangsaan Malaysia and Ministry of Higher Education under the Fundamental Research Grant Scheme FRGS/1/2017/SS01/UKM/02/3.

\section{NOTES}

1. The whole process (kit) is a Copyright of UKM.

\section{REFERENCES}

Abdullah, M., Abdul Shukor, Z., Mohamed, Z.M., \& Ahmad, A. 2015. Risk Management Disclosure: A Study on the Effect of Voluntary Risk Management Disclosure Toward Firm Value. Journal of Applied Accounting Research 16(3):400-432.

Abraham, S. \& Cox, P. 2007. Analysing the Determinants of Narrative Risk Information in UK FTSE 100 Annual Reports. The British Accounting Review 39: 227-248.

Abraham, S. \& Shrives P.J 2014. Improving the Relevance of Risk Factor Disclosure in Corporate Reports. The British Accounting Review 46:91-107.

Amran, A., Rosli A. M., \& Che Haat, M.H., 2009. Risk Reporting: An Exploratory Study on Risk Management Disclosure in Malaysian Annual Reports. Managerial Auditing Journal 24 (1): 39-57.

Bahar, R. \& Thevenoz, L. 2007. Conflicts of Interest: Disclosure, Incentives, and the Market. In L. Thévenoz and R. Bahar (Eds.), Conflicts of Interest: Corporate Governance and Financial Markets. Alphen aan den Rijn: Kluwer Law International. The Netherlands.

Balkiz, O. 2003. Testing Informational Market Efficiency on Kuala Lumpur Stock Exchange. Jurnal Ekonomi Malaysia 37: 3-20.

Barth, M. E. \& Landsman, W.R. 2010. How Did Financial Reporting Contribute to the Financial Crisis? European Accounting Review 19(3): 399-423.

Barros, C.P., Boubaker, S. \& Hamrouni, A. 2013. Corporate Governance and Voluntary Disclosure in France. The Journal of Applied Business Research 29(2):561-577.

Beretta, S. \& Bozzolan, S. 2004. A Framework for the Analysis of Firm Risk Communication. The International Journal of Accounting 39: 265-288.

Bissoon, O. 2018. Corporate Social Responsibility in Mauritius: An Analysis of Annual Reports of Multinational Hotel Groups. Asian Journal of Sustainability and Social Responsibility (2018) 3(2):1-19.

Bravo, F. 2017. Are Risk Disclosures an Effective Tool to Increase Firm Value? Managerial and Decision Economics 38(8): 1116-1124.

Bursa Malaysia. 2018. Bursa Malaysia Listing Requirements 2018. https://www.bursamalaysia.com/regulation/listing requirements/main_market/listing_requirements. (accessed on $12^{\text {th }}$ May 2020).

Cheung, Y-L, Jiang, P. \& Tan, W. 2010. A Transparency Disclosure Index Measuring Disclosures: Chinese Listed Companies. Journal of Accounting Public Policy 29: 259-280.

Cooke, T.E. 1991. An Assessment of Voluntary Disclosure in the Annual Reports of Japanese Corporations. The International Journal of Accounting 26 (3): 174-189.

Coy, D. \& Dixon, K. 2004. The Public Accountability Index: Crafting a Parametric Disclosure Index for Annual Reports. The British Accounting Review 36: 79-106.

Denning, S. 2019. Why Maximizing Shareholder Value is Finally Dying. Forbes. https://www.forbes.com/sites/stevedenn ing/2019/08/19/ why-maximizing-shareholder-value-is-finally-dying/\#747bc0e46746 (accessed on 26 May 2020)

Dobratz M.C. 2003. Putting the Pieces Together: Teaching Undergraduate Research from a Theoretical Perspective. Journal of Advance Nursing 41 (4):383-392.

Dominguez, L.R. \& Gamez, L.C.N. 2014. Corporate Reporting on Risks: Evidence from Spanish Companies. Spanish Accounting Review 17(2): 116-129. 
Drees, J., \& Heugens, P. 2013. Synthesising and Extending Resource Dependence Theory: A Meta-Analysis. Journal of Management 39 (6): 1666-1698.

Elshandidy, T., Neri, L. \& Guo, Y. 2018. Determinants and Impacts of Risk Disclosure Quality: Evidence from China. Journal of Applied Accounting Research 19(4):518-536.

Flostrand A., Pitt L., \& Bridson S. 2020. The Delphi Technique in Forecasting - A 42-year Bibliography Analysis (19752017). Technology Forecasting and Social Change 150: 1-12.

Freeman, R. E. 1984. Strategic Management: A Stakeholder Approach. Marshfield, Massachusetts: Pitman Publishing.

Frooman J. 1999. Stakeholder Influence Strategies. Academy of Management Review 24(2): 191-205.

Garefalakis, A., Sariannidis, N. \& Lemonakis, C. 2018. Narrative Disclosure Guidelines for CARs: An Operational-Based Tool. Annals of Operations Research, August:1-16.

Gray, R., Kouhy, R. \& Lavers, S. 1995. Corporate Social and Environmental Reporting: A Review of The Literature and a Longitudinal Study of UK Disclosure. Accounting, Auditing and Accountability Journal 8(2):47-77.

Hallowell M. \& Gambatese J. 2010. Qualitative Research: Application of the Delphi Method to CEM research. Journal of Construction Engineering and Management 136 (1): 99-107.

Habibi, A., Sarafrazi, A. \& Izadyar, S. 2014. Delphi Technique Theoretical Framework in Qualitative Research. The International Journal of Engineering and Science 3(4): 08-13.

Hassan, M.S. Mohd Saleh, N. Yatim, P. \& Che Abdul Rahman, M.R. 2012. Risk Management Committee and Financial Instrument Disclosure. Asian Journal of Accounting and Governance 3: 13-28.

Hayes, A. F., \& Krippendorff, K. 2007. Answering the Call for a Standard Reliability Measure for Coding Data. Communication Methods and Measures 1: 77-89.

Hefferan M. J., \& Wardner P. 2012. New Firms Old Assets Using Delphi Technique to Identify Accommodation Priorities for Knowledge-Intensive Firms. Journal of Corporate Real Estate 14 (4): 202-213.

Hooks, J., Tooley, S., \& Basnan, N., 2012. An Index of Best Practice Performance Reporting for Malaysian Local Authorities. Journal of Applied Accounting Research 13: 270-283.

Hsu C. \& Sandford B. A. 2007. The Delphi Technique: Making Sense of Consensus. Practical Assessment, Research and Evaluation 12 (10): 1-8.

Inchausti, B. G. 1997. The influence of company characteristics and accounting regulation on information disclosed by Spanish firms. European Accounting Review, 6(1): pages 45-68.

Jia J., Munro L., \& Buckby S. 2016. A Finer-Grained Approach to Assessing the Quality (“quantity and richness") of Risk Management Disclosures. Managerial Auditing Journal 31 (8/9):770-803.

Jorgensen, B. \& Kirschenheiter, M. T. 2003. Discretionary Risk Disclosure. The Accounting Review 78(2): 449-469.

Jurgens, M., Berthon, P., Papania, L. \& Shabbir, H.A. 2010. Stakeholder Theory and Practice in Europe and North America: The key to Success Lies in a Marketing Approach, Industrial Marketing Management, 39:769-775.

Kaplan, R. S. \& Mikes, A. 2012. Managing Risks: A New Framework. Harvard Business Review, June: https://hbr.org/2012/06/managing-risks-a-new-framework. (accessed on 6 April 2020)

Khlifa, H. \& Khaled Hussainey, K. 2016. The Association Between Risk Disclosure and firm Characteristics: A MetaAnalysis. Journal of Risk Research 19 (2): 181-211.

Kshetri, N. 2013. Cybercrime and Cyber-security Issues Associated with China: Some Economic and Institutional Considerations. Electronic Commerce Research 13 (1): 41-69.

Lajili, K. \& Zeghal, D. 2005. A Content Analysis of Risk Management Disclosures in Canadian Annual Reports. Canadian Journal of Administrative Sciences 22 :125-142.

Landeta J. 2006. Current validity of the Delphi method in social sciences. Technological Forecasting \& Social Sciences 73:467-482.

Lehavy, R. Li F. \& Merkley, K. 2011. The Effect of Annual Report Readability on Analyst Following and the Properties of Their Earnings Forecast. The Accounting Review 86 (3): 1087-1115.

Leopizzi, R., Lazzi, A., Venturelli, A., \& Principale, S. 2019. Nonfinancial Risk Disclosure: The State of the Art of Italian Companies. Corporate Social Responsibility and Environmental Management 27(1): 358-368.

Li, J., Pike, R. \& Haniffa, R. 2008. Intellectual Capital Disclosure and Corporate Governance Structure in UK Firms. Accounting and Business Research 38(2): 137-159.

Lin, T.C.W. 2016. The New Market Manipulation. Amory Law Journal 66: 1253-1314.

Linsley, P.M and Shrives, P.J. 2000. Risk Management and Reporting Risk in the UK. Journal of Risk 3(1):115-129.

Linsley, P.M. and Shrives, P.J. 2006. Risk Reporting: A Study of Risk Disclosures in The Annual Reports of UK Companies. The British Accounting Review 38:387-404.

Loo, R. 2002. The Delphi Method: A Powerful Tool for Strategic Management. Policing: An International Journal of Police Strategies and Management 25(4):762-769.

Madrigal, M. H., Guzmán, B. A. and Guzmán, C. A. 2015. Determinants of corporate risk disclosure in large Spanish companies: a snapshot. Contaduría y Administración 60:757-775.

Malaysian Accounting Standards Board. 2012. MFRS 7 Financial Instruments: Disclosure. http://www.masb.org.my/pdf.php?pdf=BV2018_MFRS\%207.pdfandfile_path=pdf_file. (accessed on 12 May 2020). 
Marston, C. L \& Shrives, P.J. 1991. The use of disclosure indices in accounting research: A review article. The British Accounting Review 23 (3): 195-210.

Miihkinen, A. 2012. What Drives Quality of Firm Risk Disclosure? The Impact of a National Disclosure Standard and Reporting Incentives Under IFRS. The International Journal of Accounting 47:437-468.

Miihkinen, A. 2013. The Usefulness of Firm Risk Disclosure Under Different Firm Riskiness, Investor-Interest, and Market Conditions: New Evidence from Finland. Advances in Accounting 29 (2): 312-331.

Milne, M. J., and R. W. Adler. 1999. Exploring the Reliability of Social and Environmental Disclosures Content Analysis. Accounting, Auditing \& Accountability Journal 12(2): 237-256.

Murray, K. B., \& Montanari, J. R. 1986. Strategic Management of the Socially Responsible firm: Integrating Management and Marketing Theory. Academy of Management Review 11(4), 815-827.

Ntim, C.G., Lindop, S. \& Thomas, D.A. 2013. Corporate governance and risk reporting in South Africa: A Study of Corporate Disclosures in the Pre- and Post- 2007/2008 Global Financial Crisis Periods. International Review of Financial Analysis 30: 363-383.

Neuman, W. L. 2014. Social Research Methods: Qualitative and Quantitative Approaches. Seventh Edition. Pearson Education Limited. England.

Okoli C. \& Pawlowski S.D. 2004. The Delphi Method as a Research Tool: An Example, Design Consideration and Application. Information and Management 42 (1): 15-29.

Pill J. 1971. The Delphi Method: Substance, Context, A Critique and an Annotated Bibliography. Socio-Economic Planning Sciences 5 (1): 57-71.

Tan, Y., Zeng C. C., and Elshandidy, T. 2017. Risk Disclosure, International Orientation, and Share Price Informativeness: Evidence from China. Journal of International Accounting, Auditing and Taxation 29:81-102.

Tirado-Beltrán, J. M., Cabedo, J. D \& Muñoz-Ramírez, D. E. 2020. Risk Disclosure and Cost of Equity: A Bayesian Approach, Revista CEA 6(11):25-43. Doi. 10.22430/24223182.1497.

Rowe G. \& Wright G. 1999. The Delphi Technique as a Forecasting Tool: Issue and Analysis. International Journal of Forecasting 15: 353-375.

Sahari, S. 2017. Constructing Human (Employees) Rights Disclosure Index and the Human Rights Disclosure Practice by the Listed Companies in Malaysia. Unpublished PhD Thesis, Universiti Kebangsaan Malaysia, Selangor, Malaysia.

Securities Commission Malaysia 2017. Malaysian Code on Corporate Governance 2017. Securities Commission Malaysia. Kuala Lumpur.

Semper, D.C and Beltran, J.M.T 2014. Risk Disclosure and Cost of Equity. The Spanish Case, Contaduria y Administracion 59 (4):105-135.

Shivaani MV, Jain P.K., \& Yadav S.S 2020. Development of a Risk Disclosure Index and Its Application in Indian Context. Managerial Auditing Journal 35(1):1-23.

Sundgren, S., Maki, J., \& Somoza-Lopez, A. 2018. Analyst Coverage, Market Liquidity and Disclosure Quality: A study of Fair Value Disclosure by European Real Estate Companies under IAS 40 and IFRS 13. The International Journal of Accounting 53 (1): 54-75.

Worrell, J.L., Di Gangi, P.M., \& Bush, A.A. 2013. Exploring the Use of the Dephi Method in Accounting Information Systems Research. International Journal of Accounting Information Systems 14(3): 193-208.

\section{Adibah Jamil}

Center for Governance Resilience and Accountability Studies

Faculty of Economics and Management

Universiti Kebangsaan Malaysia

Bangi 43600 Selangor

Malaysia

E-mail: adibahjamil@yahoo.com

Mohamat Sabri Hassan*

Center for Governance Resilience and Accountability Studies

Faculty of Economics and Management

Universiti Kebangsaan Malaysia

Bangi 43600 Selangor

MALAYSIA

E-mail: msabri@ukm.edu.my

Norman Mohd Salleh

Center for Governance Resilience and Accountability Studies

Faculty of Economics and Management

Universiti Kebangsaan Malaysia 
Bangi 43600 Selangor

MALAYSIA

E-mail: norman@ukm.edu.my

Rubayah Yaakob

Center for Governance Resilience and Accountability Studies

Faculty of Economics and Management

Universiti Kebangsaan Malaysia

Bangi 43600 Selangor

MALAYSIA

E-mail: rubayah@ukm.edu.my

${ }^{*}$ Corresponding author 
APPENDIX A. List of Non-Financial Categories and Items from Past Literature

\begin{tabular}{|c|c|c|}
\hline $\begin{array}{l}\text { Type of Non- } \\
\text { financial risk }\end{array}$ & Item & References \\
\hline \multirow{18}{*}{ Operational Risk } & OP1: Key person dependence risk & Miihkinen (2012) \\
\hline & $\begin{array}{l}\text { OP2: Uncommon business fluctuations in } \\
\text { demand }\end{array}$ & Miihkinen (2012) \\
\hline & OP3: Interruptions in the delivery chain & Miihkinen (2012) \\
\hline & $\begin{array}{l}\text { OP4: Price fluctuations of the factors of } \\
\text { production }\end{array}$ & Miihkinen (2012) \\
\hline & OP5: Patents and other industrial rights & Miihkinen (2012), Ntim et al. (2013) \\
\hline & OP6: Customer satisfaction & $\begin{array}{l}\text { Miihkinen (2012), Linsley \& Shrives (2006), } \\
\text { Abdullah et al. (2015) }\end{array}$ \\
\hline & OP7: Reputation and brand name erosion & Miihkinen (2012), Ntim et al. (2013) \\
\hline & OP8: Stock obsolescence and shrinkage & $\begin{array}{l}\text { Miihkinen (2012), Linsley \& Shrives (2006), } \\
\text { Abdullah et al. (2015), Ntim et al. (2013) }\end{array}$ \\
\hline & OP9: Product and service failure & $\begin{array}{l}\text { Miihkinen (2012), Linsley \& Shrives (2006), } \\
\text { Abdullah et al. (2015), Ntim et al. (2013) }\end{array}$ \\
\hline & OP10: Environmental issues/impact & $\begin{array}{l}\text { Miihkinen (2012), Linsley \& Shrives (2006), } \\
\text { Abdullah et al. (2015), Ntim et al. (2013) }\end{array}$ \\
\hline & OP11: Health and Safety & $\begin{array}{l}\text { Miihkinen (2012), Linsley \& Shrives (2006), } \\
\text { Abdullah et al. (2015), Ntim et al. (2013) }\end{array}$ \\
\hline & OP12: Unsuccessful project deliveries & Miihkinen (2012) \\
\hline & OP13: Quality control & Miihkinen (2012) \\
\hline & OP14: Product development & $\begin{array}{l}\text { Linsley \& Shrives (2006), Abdullah et al. } \\
\text { (2015), Ntim et al. (2013) }\end{array}$ \\
\hline & OP15: Business process and procedure & Ntim et al. (2013) \\
\hline & OP16: Sourcing & $\begin{array}{l}\text { Linsley \& Shrives (2006), Abdullah et al. } \\
\text { (2015), Ntim et al. (2013) }\end{array}$ \\
\hline & $\begin{array}{l}\text { OP17: Compliance on operations } \\
\text { regulations }\end{array}$ & Ntim et al. (2013) \\
\hline & $\begin{array}{l}\text { OP18: Social contribution / community } \\
\text { support }\end{array}$ & Ntim et al. (2013) \\
\hline \multirow[t]{7}{*}{ Empowerment Risk } & $\begin{array}{l}\text { EM1: Governance, leadership and } \\
\text { management }\end{array}$ & $\begin{array}{l}\text { Linsley \& Shrives (2006), Abdullah et al. } \\
\text { (2015) }\end{array}$ \\
\hline & EM2: Outsourcing & $\begin{array}{l}\text { Linsley \& Shrives (2006), Abdullah et al. } \\
\text { (2015) }\end{array}$ \\
\hline & EM3: Performance incentives & $\begin{array}{l}\text { Linsley \& Shrives (2006), Abdullah et al. } \\
\text { (2015) }\end{array}$ \\
\hline & $\begin{array}{l}\text { EM4: Resistance to change/ adaption } \\
\text { /Change readiness }\end{array}$ & $\begin{array}{l}\text { Linsley \& Shrives (2006), Abdullah et al. } \\
(2015))\end{array}$ \\
\hline & EM5: Communications & $\begin{array}{l}\text { Linsley \& Shrives (2006), Abdullah et al. } \\
\text { (2015) }\end{array}$ \\
\hline & High employee turn & Ntim et al. (2013) \\
\hline & EM7: Productivity of staff & Ntim et al. (2013) \\
\hline \multirow{5}{*}{$\begin{array}{c}\text { Information } \\
\text { Processing and } \\
\text { Technology Risk }\end{array}$} & $\begin{array}{l}\text { IT1: System' safety and security } \\
\text { (Integrity) }\end{array}$ & $\begin{array}{l}\text { Linsley \& Shrives (2006), Maizatulakma et al. } \\
\text { (2015) }\end{array}$ \\
\hline & $\begin{array}{l}\text { IT2: Accessibility by unauthorized } \\
\text { personnel }\end{array}$ & $\begin{array}{l}\text { Linsley \& Shrives (2006), Abdullah et al. } \\
\text { (2015) }\end{array}$ \\
\hline & IT3: Availability of information & $\begin{array}{l}\text { Linsley \& Shrives (2006), Abdullah et al. } \\
\text { (2015) }\end{array}$ \\
\hline & IT4: Infrastructure & $\begin{array}{l}\text { Linsley \& Shrives (2006), Abdullah et al. } \\
\text { (2015) }\end{array}$ \\
\hline & IT5: Cybercrime & Suggested by Pre-test Panelist \\
\hline \multirow[t]{3}{*}{ Integrity Risk } & $\begin{array}{l}\text { IN1: Management and employee fraud / } \\
\text { illegal acts }\end{array}$ & $\begin{array}{l}\text { Ntim et al (2013); Linsley \& Shrives (2006), } \\
\text { Abdullah et al. (2015) }\end{array}$ \\
\hline & IN2: Reputation & $\begin{array}{l}\text { Linsley \& Shrives (2006), Abdullah et al. } \\
\text { (2015) }\end{array}$ \\
\hline & IN3: Conflict of interest & Suggested by Pre-test Panelist \\
\hline
\end{tabular}




\begin{tabular}{|c|c|c|}
\hline \multirow[t]{24}{*}{ Strategy Risk } & ST1: Market competition & Miihkinen (2012) \\
\hline & ST2: Market Area & Miihkinen (2012) \\
\hline & ST3: Position in the production chain & Miihkinen (2012) \\
\hline & ST4: Too dependence on customer & Miihkinen (2012) \\
\hline & ST5: Too dependence on suppliers & Miihkinen (2012) \\
\hline & ST6: Changes in technological progress & Miihkinen (2012) \\
\hline & ST7: Regulatory changes & $\begin{array}{l}\text { Miihkinen (2012), Linsley \& Shrives (2006), } \\
\text { Abdullah et al. (2015), Ntim et al. (2013) }\end{array}$ \\
\hline & ST8: Political changes & $\begin{array}{l}\text { Miihkinen (2012), Linsley \& Shrives (2006), } \\
\text { Abdullah et al. (2015), Ntim et al. (2013) }\end{array}$ \\
\hline & ST9: Economical changes & Miihkinen (2012) \\
\hline & ST10: Mergers and acquisitions & Miihkinen (2012) \\
\hline & ST11: Pricing & $\begin{array}{l}\text { Miihkinen (2012), Linsley \& Shrives (2006), } \\
\text { Abdullah et al. (2015) }\end{array}$ \\
\hline & ST12: Industry specific changes & $\begin{array}{l}\text { Miihkinen (2012), Linsley \& Shrives (2006), } \\
\text { Abdullah et al. (2015) }\end{array}$ \\
\hline & ST13: Launching of new products & Miihkinen (2012) \\
\hline & ST14: Business portfolio changes & $\begin{array}{l}\text { Miihkinen (2012), Linsley \& Shrives (2006), } \\
\text { Abdullah et al. (2015) }\end{array}$ \\
\hline & ST15: Business life cycle & $\begin{array}{l}\text { Miihkinen (2012), Linsley \& Shrives (2006), } \\
\text { Abdullah et al. (2015) }\end{array}$ \\
\hline & $\begin{array}{l}\text { ST16: Changes in management team } \\
\text { (Management) }\end{array}$ & Miihkinen (2012) \\
\hline & ST17: Competitors presence & $\begin{array}{l}\text { Linsley \& Shrives (2006), Abdullah et al. } \\
\text { (2015) }\end{array}$ \\
\hline & $\begin{array}{l}\text { ST18: Valuation of asset, liabilities and } \\
\text { stock }\end{array}$ & $\begin{array}{l}\text { Linsley \& Shrives (2006), Abdullah et al. } \\
\text { (2015) }\end{array}$ \\
\hline & $\begin{array}{l}\text { ST19: Strategic planning process } \\
\text { (Planning) }\end{array}$ & $\begin{array}{l}\text { Linsley \& Shrives (2006), Abdullah et al. } \\
(2015))\end{array}$ \\
\hline & ST20: Performance measurement & $\begin{array}{l}\text { Linsley \& Shrives (2006), Abdullah et al. } \\
\text { (2015) }\end{array}$ \\
\hline & ST21: Taxation policy changes & Ntim et al. (2013) \\
\hline & $\begin{array}{l}\text { ST22: GDP growth/market demand/ } \\
\text { aggregate demand }\end{array}$ & Ntim et al. (2013) \\
\hline & ST23: Inflation rate changes & Ntim et al. (2013) \\
\hline & ST24: Budget deficit & Ntim et al. (2013) \\
\hline \multirow[t]{3}{*}{$\begin{array}{c}\text { Research and } \\
\text { Development Risk }\end{array}$} & $\begin{array}{l}\text { RD1: Company's plan on new products } \\
\text { or services }\end{array}$ & Tan et al. (2017) \\
\hline & $\begin{array}{l}\text { RD2: Incompleteness of going Research } \\
\text { and Development projects }\end{array}$ & Tan et al. (2017) \\
\hline & $\begin{array}{l}\text { RD3: Breach of trust on Research and } \\
\text { Development's confidentiality }\end{array}$ & Tan et al. (2017) \\
\hline \multirow{2}{*}{$\begin{array}{l}\text { Damage and Hazard } \\
\text { Risk }\end{array}$} & DH1: Significant illegal actions & Miihkinen (2012) \\
\hline & DH2: Natural disasters and/or terrorism & Ntim et al. (2013) \\
\hline
\end{tabular}

IN4: Evasion or avoidance of tax regulation

IN5: Market manipulation activities
Suggested by Pre-test Panelist

Suggested by Pre-test Panelist
Miihkinen (2012)
Miihkinen (2012)
Miihkinen (2012)
Miihkinen (2012)
Miihkinen (2012)
Miihkinen (2012)

Miihkinen (2012), Linsley \& Shrives (2006),

Miihkinen (2012)

Miihkinen (2012), Linsley \& Shrives (2006),

Miihkinen (2012), Linsley \& Shrives (2006),

Miihkinen (2012), Linsley \& Shrives (2006),

ey \& Shrives (2006)

\section{(Management)}

ST18: Valuation of asset, liabilities and

Linsley \& Shrives (2006), Abdullah et al (2015)

Ntim et al. (2013)

Ntim et al. (2013)

Ntim et al. (2013) 